\title{
GREEN SYNTHESIZED QUANTUM DOTS AS ELECTROCHEMICAL LABELS FOR SENSITIVE DETECTION OF HEMORRHAGIC FEVER VIRUS
}

\author{
${ }^{1,2}$ Božena HOSNEDLOVA, ${ }^{2,3}$ Karel SEHNAL, ${ }^{2} Z$ uzana TOTHOVA, ${ }^{4}$ Marta KEPINSKA, \\ ${ }^{3}$ Branislav RUTTKAY-NEDECKY, ${ }^{5}$ Carlos FERNANDEZ, ${ }^{6}$ Augustine Enakpodia OFOMAJA, \\ ${ }^{4}$ Halina MILNEROWICZ, ${ }^{1,2,3,4}$ René KIZEK \\ ${ }^{1}$ Department of Food and Feed Safety, Veterinary and Research Institute, Brno, Czech Republic, EU, \\ bozena.hosnedlova@post.cz \\ ${ }^{2}$ Department of Research and Development, Prevention Medicals s.r.o., Studénka-Butovice, \\ Czech Republic, EU, uhlirova@preventionmedicals.cz \\ ${ }^{3}$ Department of Human Pharmacology and Toxicology, University of Veterinary and Pharmaceutical \\ Sciences Brno, Czech Republic, EU, kizek@sci.muni.cz \\ ${ }^{4}$ Department of Biomedical and Environmental Analyses, Faculty of Pharmacy with Division of Laboratory \\ Diagnostics, Wroclaw Medical University, Wroclaw, Poland, EU, zalewska.m@gmail.com \\ ${ }^{5}$ School of Pharmacy and Life Sciences, Robert Gordon University, Garthdee Road, Aberdeen, \\ Scotland, United Kingdom, EU, c.fernandez@rgu.ac.uk
}

${ }^{6}$ Biosorption and Wastewater Treatment Research Laboratory, Department of Chemistry, Faculty of Applied and Computer Sciences, Vaal University of Technology, Vanderbijlpark, South Africa, augustineo@vut.ac.za

https://doi.org/10.37904/nanocon.2019.8650

\begin{abstract}
Virus-induced haemorrhagic fevers often show a rapid, dramatic course. Infectivity and mortality are very high. Such viruses are known to attack primates as well as other animal species. Fast, sensitive, selective diagnostics can be very beneficial for early anti-epidemic measures right in the outbreak. Quantum dots (QDs) have excellent features that make them useful as detection labels. Their use increases the sensitivity of the analytical assay. The use of biologically active components in QDs synthesis brings new properties. Quantum dots are nanocrystals that due to their high stability, ease of preparation and biocompatibility are suitable for labeling biomolecules. CdTe QDs modified with mercaptosuccinic acid (MSA), reduced glutathione (GSH), and plant extracts were prepared. Green synthesized CdTe QDs showed emission depending on the amount of extract applied. Thus, QDs were prepared in full-color scale from blue to red. The modified biomolecules of QDs are applicable for the labeling of nucleic acids. Their long-term stability, including their application onto paper, was tested. CdTe QDs exhibit very good electrochemical detection with the limit of detection (LOD) in nanomolar concentration.
\end{abstract}

Keywords: Dangerous viral diseases, QDs, green synthesis, viral infection, CdTe, sensors, electrochemistry, electrochemical biosensor

\section{INTRODUCTION}

Quantum dots (QDs) are semiconductor nanocrystals (their size varies from 1 to $20 \mathrm{~nm}$ ) that have been described about 40 years ago. The quantum dot is composed of 100 to 100,000 atoms. These nanocrystals are formed by the action of reducing agents in thermal synthesis [1-3]. It is possible to replace chemical reducing agents with mixtures (bio-extracts) [4]. Biosynthesis is a new way of synthesizing nanomaterials. The main advantage of this method is its environmental friendliness and further reduction of toxicity [5,6]. In addition, some of the substances contained in the extracts may have other significant biological properties [7]. If QDs are biosynthesized outside the organism, we are talking about extracellular synthesis. This type of 
synthesis allows nanoparticle size control by means of temperature or $\mathrm{pH}$. Intracellular synthesis takes place within the cells of the organism, nanoparticles are formed and deposited inside the cells. Nanoparticles prepared in this way are intricately separated from the organism. QDs are used in nanomedicine as fluorescent labels, mainly due to their fluorescence capabilities. They are used in microscopy for labeling tissues, cells and antibodies, as well as in medicine for the delivery and location of drugs, for the detection and monitoring of diseases. Their future uses include targeted tumor therapy. They are being used in photodynamic therapy (PTD) as an effective diagnostic treatment for tumor growth. PDT is used for local treatment of less developed tumors. Its principle is the application of a photosensitive substance that accumulates preferentially in the fastest-dividing (tumor) cells, causing the cells to die after irradiation with light. QDs can be used as detection labels when they are used as a biosensor [8]. African Swine Fever Virus (ASFV) is a DNA virus of the Asfivirus genus of the Asfarviridae family that is found in blood, body fluids, internal organs and all secretions and excretions and can be secreted 1-2 days before clinical symptoms [9]. ASFV was described more than 40 years ago. This virus spreads pandemically among members of the Suidae family, and the mortality rate of the virus-related disease is approaching $100 \%$ [10]. The design and construction of sensors/biosensors require very sensitive detection and recognition parts. Very sensitive tools for analyte identification are fluorescence methods. In addition to their fluorescence properties, their electrochemical behaviour can be used. CdTe detection limits may be in $\mathrm{nM}$. The aim of this work was to propose a procedure for QDs modification and their sensitive electrochemical detection. The quantum dots served as labels that would be usable for DNA biosensor design.

\section{MATERIAL AND METHODS}

Chemicals. All chemicals used in this study such as $\mathrm{Cd}\left(\mathrm{CH}_{3} \mathrm{COO}\right)_{2} \cdot 2 \mathrm{H}_{2} \mathrm{O}, \mathrm{Na}_{2} \mathrm{TeO}_{3}$, mercaptosuccinic acid (MSA), Trizma base, KING F: 5'-CTGCTCATGGTATCAATCTTATCGA-3', KING R: 5'GATACCACAAGATCAGCCGT-3' and HCl were purchased from Sigma-Aldrich (St. Louis, MO, USA), in ACS purity. Propanol and $\mathrm{NaBH}_{4}$ were purchased from Merck (Darmstadt, Germany). All plastic materials used (tubes, tips) in this study were purchased from Eppendorf (Hamburg, Germany). Deionised water was prepared by using the reverse osmosis equipment Aqual 25 (Brno, Czech Republic), and was further purified by using an ELGA apparatus equipped with a UV lamp (Lane End, United Kingdom). The resistance was $18 \mathrm{M} \Omega$ and the $\mathrm{pH}$ was measured using the $\mathrm{pH}$ meter (WTW).

Instruments. For absorption spectra, the wavelength was in the range from 400 to $800 \mathrm{~nm}$. For fluorescence spectra, there were an excitation wavelength of $250 \mathrm{~nm}$ and an emission wavelength in the range from 350 to $800 \mathrm{~nm}$ (Varioskan, Thermo Fisher Scientific, USA). The optical properties of nanoparticles were studied by spectral analysis. The absorbance spectra of nanoparticles were recorded within the range of 400 to $800 \mathrm{~nm}$ using a UV-3100PC UV-VIS spectrophotometer (VWR, Germany).

CdTe quantum dots synthesis. The preparation of CdTe quantum dots (QDs) was performed as follows: 10 $\mathrm{mL}$ of solution $\mathrm{Cd}\left(\mathrm{CH}_{3} \mathrm{COO}\right)_{2} \cdot 2 \mathrm{H}_{2} \mathrm{O}(0.02 \mathrm{M}), 76 \mathrm{~mL}$ of $\mathrm{H}_{2} \mathrm{O}, 1 \mathrm{~mL}$ of mercaptosuccinic acid (MSA) solution $(0.4 \mathrm{M}), 5 \mathrm{~mL}$ of $\mathrm{Na}_{2} \mathrm{TeO}_{3}(0.02 \mathrm{M})$, and $40 \mathrm{mg}$ of $\mathrm{NaBH}_{4}$ were stirred with a magnetic stirrer (VMS-C4, VWR International Ltd., Darmstadt, Germany) for at least two hours until the bubbling stopped. Subsequently, the volume was adjusted to $100 \mathrm{~mL}$. Then $2 \mathrm{~mL}$ of the prepared solution was pipetted into the glass vials (Sigma Aldrich, St. Louis, MO, USA) with a white cap (Anton Paar, Graz, Austria) and a Teflon cap (Anton Paar, Graz, Austria). The vial containing the mixture was placed in a microwave. During CdTe QDs synthesis using GSH $1 \mathrm{~mL}$ of MSA solution $(0.4 \mathrm{M})$ was replaced with mixture containing $0.8 \mathrm{~mL}$ of MSA solution $(0.4 \mathrm{M})$ and 0.2 $\mathrm{mL}$ of GSH solution $(1 \mathrm{mM})$ in the $4: 1$ variant or $0.5 \mathrm{~mL}$ of MSA solution and $0.5 \mathrm{~mL}$ of GSH solution in the 1 : 1 variant. During CdTe QDs biosynthesis, an extract from maize leaves was used together with MSA solution ( $0.1 \mathrm{~mL}$ of maize extract and $0.9 \mathrm{~mL}$ of $0.4 \mathrm{M} \mathrm{MSA}$ solution). The preparation of the maize extract was as follows: $1 \mathrm{~g}$ of maize leaves were homogenized using mortar and pestle with sand into $2 \mathrm{~mL}$ of phosphate 
buffer, then the mixture was shaken for $15 \mathrm{~min}$, and finally, the extract was separated by centrifugation at $10000 \mathrm{~g}$ for $15 \mathrm{~min}$. Surface morphology of the nanoparticles was investigated with field emission scanning electron microscopy (FESEM) using an operating voltage of $10 \mathrm{kV}$ in the SEM (Zeiss) instrument. Surface charging effect was minimized by coating the samples with gold on copper stubs with a coating instrument. Transmission electron microscope (TEM) and higher resolution TEM (JEOL) were determined on a copper stub with carbon glue and coated with gold before analysis. The samples for TEM and HRTEM were placed in vials containing absolute ethanol and ultrasonicated for $10 \mathrm{~min}$. Thereafter, holey/lacey carbon grids (10 $\mu \mathrm{m})$ were dipped into the vials containing the ultrasonicated samples and dried before microstructural determination. Determination of ODNs and $\mathrm{Cd}^{2+}$ by difference pulse voltammetry (DPV) was performed at 663 VA Stand (Metrohm, Switzerland). A standard cell with three electrodes was used, and a hanging mercury drop electrode (HMDE) with a drop area of $0.4 \mathrm{~mm}^{2}$ was employed as the working electrode. $\mathrm{An} \mathrm{Ag} / \mathrm{AgCl} / 3 \mathrm{M}$ $\mathrm{KCl}$ electrode acted as the reference and a carbon electrode was auxiliary. For data processing, VA database software by Metrohm was employed. The analysed samples were deoxygenated prior to measurements by purging with argon $(99.999 \%) .0 .2 \mathrm{M}$ acetate buffer $(\mathrm{pH}=5)$ was used as a supporting electrolyte. The parameters of the measurement were as follows: initial potential $-1.2 \mathrm{~V}$, end potential $0 \mathrm{~V}$, deoxygenating with argon $120 \mathrm{~s}$, accumulation time $120 \mathrm{~s}$, step potential $5 \mathrm{mV}$, modulation amplitude $25 \mathrm{mV}$, the volume of injected sample: $50 \mu \mathrm{L}$ and volume of measurement cell $10 \mathrm{~mL}$. CdTe QD-modified ODNs were analyzed using the adsorptive transfer method.

Statistical analysis of data. Experimental work was performed in at least three independent experiments. Each sample in the experiments was analysed at least five times. The obtained data presented in this paper are the average values. No experimental points were excluded from the proposed experimental study. All the obtained data were stored in the Qinslab database (Prevention Medicals, Czech Republic). If possible, data were processed and evaluated mathematically and statistically in the Qinslab database. The results were expressed as mean \pm standard deviation (SD).

\section{RESULTS AND DISCUSSION}

In this work, we focused on possibilities of using plant extract for QDs preparation. CdTe QDs were prepared using modification of MSA, GSH, and maize leaf extract. Thermal synthesis of QDs was carried out in a microwave at $300 \mathrm{~W}$, with only 3 minutes of synthesis producing green and yellow dots, orange dots appeared after 4 minutes of thermal synthesis and red dots began to form after 5 minutes. Different particle formation rate is due to the size of QDs. In another experimental work, we focused on assessing the possible substitution of modifying agents in the QDs preparation process. Quantum dots were made by chemical synthesis using MSA. Typical color variants were obtained (Figure 1). The synthesis process was very reproducible, so a slight modification of the chemical synthesis was undertaken. MSA was added at the end of the reaction solution preparation process. After 3 minutes of thermal synthesis, green and yellow quantum dots were formed, after 4 minutes orange quantum dots were created. Red quantum dots formed after 4-5 minutes of synthesis. All manufactured QDs modified (MODI) were fluorescent.

QDs MODI printed on filter paper were also characterized to determine their stability. All samples were fluorescent for more than 6 months. Quantum dots were also produced by replacing part of MSA with GSH. Two variants of MSA : GSH $4: 1$ and $1: 1$ ratios were prepared. In the $4: 1$ ratio of reducing agents, yellow, green, and blue QDs MSA : GSH were formed after the thermal synthesis. The blue color may be due to the small core size of the QDs or the modified surface. In a $1: 1$ ratio of MSA : GSH, QDs MSA : GSH were yellow and orange. All QDs MSA : GSH formed were fluorescent. Quantum dots synthesized with MSA : GSH reducing agents in $4: 1$ and $1: 1$ ratios were printed on filter paper. All loaded samples showed fluorescence properties. Quantum dots were made also biosynthetically. MSA was added at a $9: 1$ ratio with a maize leaf extract. 
$\mathbf{A}$

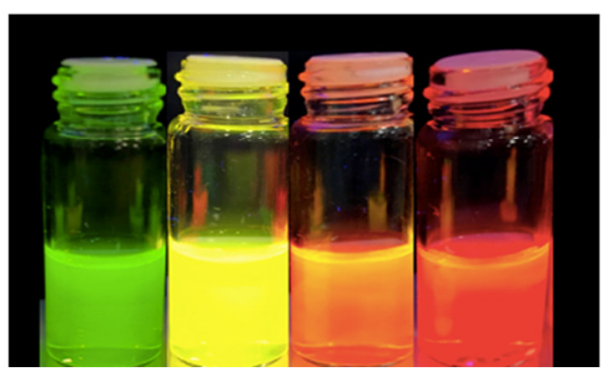

B

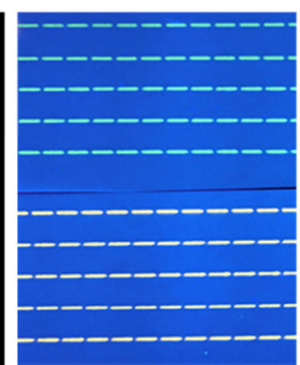

C

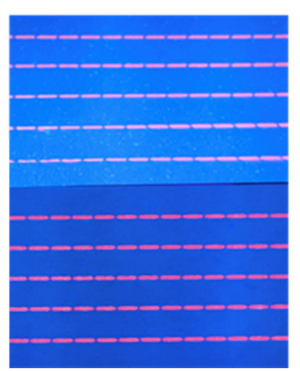

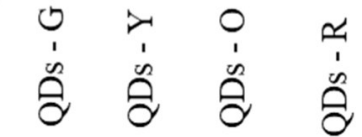

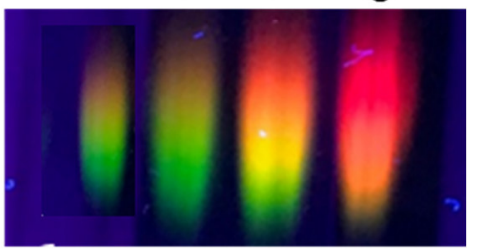

Figure $1 \mathrm{CdTe}$ QDs MODI, a typical color spectrum after microwave synthesis (A) Photographic documentation of CdTe QDs printed on filter paper and subsequently photographed on a transluminator (260 $\mathrm{nm}$ ). (B) SDS PAGE of CdTe QDs. $10 \mu \mathrm{L}$ of a sample was applied to the gel. (C) Fluorescence under UV lamp $310 \mathrm{~nm}, 5 \mathrm{~mW}$.

A

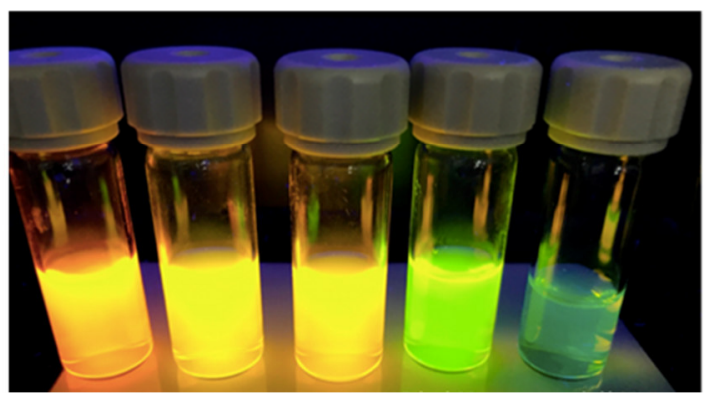

B

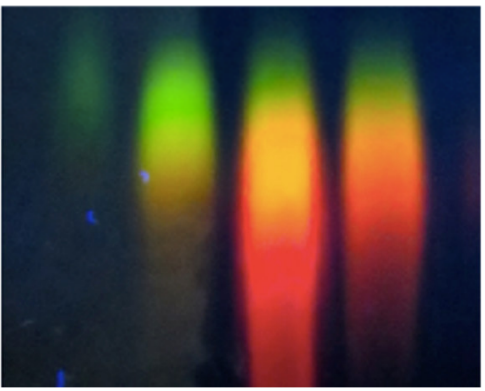

C

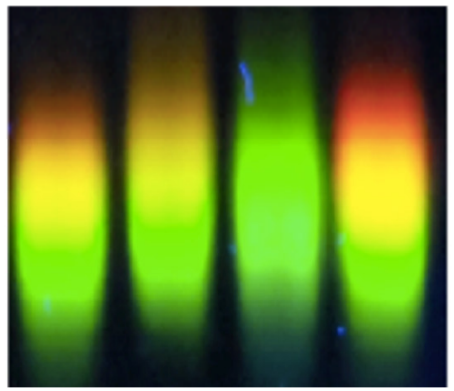

Figure 2 CdTe QDs fluorescence synthesized using MSA : GSH in a $4: 1$ ratio. Yellow, green and blue quantum dots (A) were observed. (B) SDS PAGE of CdTe QDs MSA : GSH. (C) SDS PAGE of CdTe QDs GPE (they were made biosynthetically using maize leaf extract). $10 \mu \mathrm{L}$ of a sample was applied to the gel. Fluorescence was recorded under a UV lamp of $310 \mathrm{~nm}$ and $5 \mathrm{~mW}$.

Plants were transferred to the hydroponic growth system with only aerated distilled water with a different concentration of cadmium $\left(\mathrm{Cd}^{2+}\right)$ ions. It is known that $\mathrm{Cd}^{2+}$ reduces the activity of antioxidant enzymes and thus increase cell damage [11]. After thermal synthesis, the QDs green, yellow, and red were formed and all were fluorescent. The stability of QDs was monitored over several weeks and was very good. The design of our experiment is the development of a suitable sensor/biosensor using QDs. It is known that organisms on Earth protect themselves from heavy metal ions by their binding to thiol compounds (glutathione, phytochelatins, metallothioneins) [12,13]. For such purposes, it is necessary to provide sufficient stability of the prepared nanomaterial. For this purpose, we have applied QDs to a suitable carrier (a paper in our case). QDs were applied by printing. After printing, the samples were tested for fluorescence. Individual images were scanned and evaluated by ColorTest. We found that a change in fluorescence of up to $10 \%$ was observed within 6 months. We assume that QDs prepared by us are stable over the long term. Quantum dots CdTe/MSA, CdTe/MSA MODI, CdTe/MSA GSH, CdTe/GPE were printed on paper. Each sample was printed in 15 replicates. The individual samples were loaded in a volume of $4 \mu \mathrm{L}$ of the sample, the printing speed was 10 $\mu \mathrm{L} / \mathrm{s}$, the band length was $5 \mathrm{~mm}$. The carrier gas was nitrogen (purity 5.0 ) at $5 \mathrm{kPa}$. After sample loading, the paper was irradiated with UV light ( 365 and $230 \mathrm{~nm}$ ) and the image was taken (10 mPx). For the diagnosis of serious viral infections, new ways are sought $[14,15]$. The amount of cadmium was analysed electrochemically. A proposed scheme of the detection part of the prepared biosensor for detecting viral particles is shown in 
Figure 3. The CdTe QDs were subsequently electrochemically determined on the working electrode. All QDs used have been found to provide very good electrochemical signals (typical green, yellow, orange, and red QDs signals). The CdTe QDs calibration relationship was linear $(r=0.999$, LOD $=0.5 \mathrm{nM})$. The proposed detection system was used to analyse viral particles with very good repeatability (RSD up to $10 \%$ ). Detailed information on created QDs is summarized in Table 1.

Table 1 Spectrometric characterization of various types of CdTe QDs

\begin{tabular}{|c|c|c|c|c|c|c|}
\hline Type of CdTe QDs & $\begin{array}{c}\text { Absorbance } \\
\text { maximum }^{\mathrm{a}}(\mathrm{nm})\end{array}$ & SD & Excitation (nm) & Emission (nm) & $\begin{array}{c}\text { Difference Ex- } \\
\text { Em }^{\mathrm{b}}\end{array}$ & Color \\
\hline CdTe QDs-MSA-1 & 311 & 3.6 & 409 & 436 & -27 & red \\
\hline CdTe QDs-MSA-2 & 267 & 24.0 & 317 & 436 & -119 & yellow \\
\hline CdTe QDs-MSA-3 & 279 & 35.8 & 398 & 432 & -34 & red \\
\hline CdTe QDs-MSA-4 & 247 & 15.9 & 398 & 438 & -40 & red \\
\hline Average & 276 & 20 & 381 & 436 & -55 & \\
\hline CdTe QDs-GSH-1 & 337 & 1.7 & 388 & 442 & -54 & red \\
\hline CdTe QDs-GSH-2 & 331 & 1.5 & 395 & 441 & -46 & red \\
\hline CdTe QDs-GSH-3 & 310 & 3.1 & 382 & 440 & -58 & red \\
\hline CdTe QDs-GSH-4 & 308 & 1.0 & 389 & 444 & -55 & red \\
\hline CdTe QDs-GSH-5 & 299 & 1.0 & 386 & 444 & -58 & red \\
\hline CdTe QDs-GSH-6 & 317 & 1.5 & 384 & 444 & -60 & red \\
\hline Average & 317 & 2 & 387 & 443 & -55 & \\
\hline CdTe QDs-extract-1 & 250 & 4.3 & 337 & 446 & -109 & orange \\
\hline CdTe QDs-extract-2 & 250 & 3.6 & 347 & 446 & -99 & orange \\
\hline CdTe QDs-extract-3 & 260 & 2.0 & 349 & 440 & -91 & orange \\
\hline CdTe QDs-extract-4 & 256 & 7.3 & 339 & 446 & -107 & orange \\
\hline CdTe QDs-extract-5 & 258 & 4.5 & 338 & 441 & -103 & orange \\
\hline CdTe QDs-extract-6 & 265 & 5.8 & 355 & 444 & -89 & green \\
\hline CdTe QDs-extract-7 & 268 & 3.2 & 349 & 449 & -100 & green \\
\hline CdTe QDs-extract-8 & 265 & 5.8 & 351 & 446 & -95 & green \\
\hline CdTe QDs-extract-9 & 268 & 3.2 & 355 & 447 & -92 & green \\
\hline CdTe QDs-extract-10 & 260 & 2.1 & 362 & 442 & -80 & green \\
\hline Average & 260 & 4 & 348 & 445 & -97 & \\
\hline CdTe QDs-MOD-1 & 302 & 1.7 & 331 & 419 & -88 & yellow \\
\hline CdTe QDs-MOD-2 & 302 & 3.0 & 396 & 420 & -24 & orange-red \\
\hline CdTe QDs-MOD-3 & 317 & 2.1 & 217 & 412 & -195 & red \\
\hline CdTe QDs-MOD-4 & 301 & 0.6 & 475 & 429 & 46 & yellow \\
\hline CdTe QDs-MOD-5 & 256 & 7.0 & 309 & 417 & -108 & red \\
\hline Average & 296 & 3 & 346 & 419 & -74 & - \\
\hline
\end{tabular}

${ }^{a}$ Average VIS spectra $(300-700 \mathrm{~nm}), \mathrm{n}=3$

${ }^{\mathrm{b}}$ The difference was calculated as follows: Excitation - Emission

SD - standard deviation 


\section{ELECTROCHEMICAL HYBRIDIZATION SENSOR}

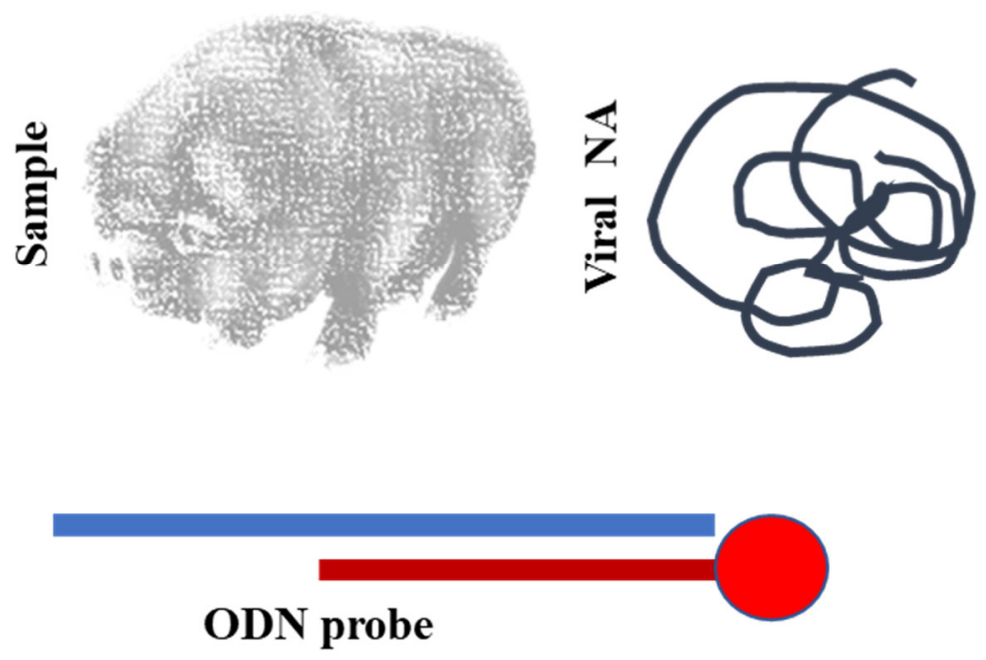

\section{QDs - ODN probe}
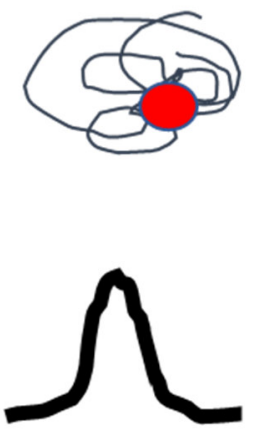

Signal of QDs

Figure 3 Scheme of CdTe QDs hybridization biosensor. A sample originating from the infected organism is collected. Viral nucleic acid from samples is isolated by standard protocol. The prepared specific hybridization probe labeled with CdTe QDs binds to the target nucleic acid. The electrochemical signal of the presence of CdTe QDs is monitored.

As for viral nucleic analysis, CdTe QD-modified ODNs were analyzed by the adsorptive transfer method. Due to this technique, ODNs and QDs unadsorbed to the working electrode surface were washed away. The electrochemical reduction signal of adenine and cytosine (CA signal) and the cadmium redox signal from CdTe were obtained. The average signals of the potentials are summarized in Table 2. The potential of CdTe QDs to ODN bound was around $-0.58 \mathrm{~V}$ and the potential for QDs alone was $-0.56 \mathrm{~V}$. The CA signal was around $1.30 \mathrm{~V}$ for unmodified ODNs, and for modified ODNs, the signal was shifted very slightly to a more negative potential around $-1.31 \mathrm{~V}$. In addition, differences between ODN signals ( $/ p$, Ep) after their interaction with QDs have been demonstrated.

Table 2 The average signals of the potentials

\begin{tabular}{lcc}
\multicolumn{1}{c}{ Experimental analysis } & Cd signal (V) & CA signal (V) \\
\hline KING F/CdTe QDs & $-0.58 \pm 0.003$ & $-1.31 \pm 0.003$ \\
KING R/CdTe QDs & $-0.58 \pm 0.001$ & $-1.30 \pm 0.002$ \\
CdTe QDs & $-0.56 \pm 0.002$ & n.d. \\
\hline $\mathrm{n}=10$ & & \\
n.d. - non-detected & &
\end{tabular}

\section{CONCLUSION}

So far, very little information about the green synthesis of QDs is known. In this study, green synthesis of CdTe QDs is presented. Various modified CdTe QDs were prepared. The prepared QDs evinced high stability making them suitable for ODN labeling. Based on the results, it can be concluded that the changes in the structure of the DNA can significantly affect the electrochemical behavior and these changes should be taken into account in its detection. In addition, the findings can be used to design new types of biosensors. 


\section{ACKNOWLEDGEMENTS}

The work was realized thanks to the project QK1920113 and international collaboration project of The European Technology Platform for Nanomedicine. Carlos Fernandez would like to express his gratitude to RGU for its support. The authors would like to thank Markéta Zelinková for the preparation of various types of QDs and Mert Pay for the technical assistance in QDs analysis.

\section{REFERENCES}

[1] FRENETTE, L. C., KRAUSS, T. D. Uncovering active precursors in colloidal quantum dot synthesis. Nat. Commun., 2017, vol. 8, no. Article Number: 2082 pp. 1-8.

[2] OH, E., LIU, R., NEL, A., GEMILL, K. B., BILAL, M., COHEN, Y.,MEDINTZ, I. L. Meta-analysis of cellular toxicity for cadmium-containing quantum dots. Nat. Nanotechnol., 2016, vol. 11, no. 5, pp. 479-486.

[3] YUAN, B., EGNER, T. K., VENDITTI, V.,CADEMARTIRI, L. Sustainable scalable synthesis of sulfide nanocrystals at low cost with an ionic liquid sulfur precursor. Nat. Commun., 2018, vol. 9, no. Article Number: 4078 pp. 1-7.

[4] SAVAGE, N. A fresh brew. Nature, 2019, vol. 566, no. pp. S14-S14.

[5] TARAKINA, N. V.,VERBERCK, B. A portrait of cadmium. Nat. Chem., 2017, vol. 9, no. 1, pp. 96-96.

[6] LEITNER, W. Green chemistry - Frontiers in benign chemical syntheses and processes. Science, 1999, vol. 284, no. 5421, pp. 1780-1781.

[7] ARABYAN, E., HAKOBYAN, A., KOTSINYAN, A., KARALYAN, Z., ARAKELOV, V., ARAKELOV, G., NAZARYAN, K., SIMONYAN, A., AROUTIOUNIAN, R., FERREIRA, F.,ZAKARYAN, H. Genistein inhibits African swine fever virus replication in vitro by disrupting viral DNA synthesis. Antivir. Res., 2018, vol. 156, no. pp. 128-137.

[8] DUARTE, J. H. DNA cages target quantum dots. Nat. Biotechnol., 2016, vol. 34, no. 10, pp. 1036-1036.

[9] GALINDO, I.,ALONSO, C. African Swine Fever Virus: A Review. Viruses, 2017, vol. 9, no. 5, pp. 103-113.

[10] GE, S. Q., LI, J. M., FAN, X. X., LIU, F. X., LI, L., WANG, Q. H., REN, W. J., BAO, J. Y., LIU, C. J., WANG, H., LIU, Y. T., ZHANG, Y. Q., XU, T. G., WU, X. D.,WANG, Z. L. Molecular Characterization of African Swine Fever Virus, China, 2018. Emerg. Infect. Dis., 2018, vol. 24, no. 11, pp. 2131-2133.

[11] WINIARSKA-MIECZAN, A. Protective effect of tea against lead and cadmium-induced oxidative stressa review. Biometals, 2018, vol. 31, no. 6, pp. 909-926.

[12] RIZWAN, M., ALI, S., REHMAN, M. Z. U., RINKLEBE, J., TSANG, D. C. W., BASHIR, A., MAQBOOL, A., TACK, F. M. G.,OK, Y. S. Cadmium phytoremediation potential of Brassica crop species: A review. Sci. Total Environ., 2018, vol. 631-632, no. pp. 1175-1191.

[13] GAWEL, J. E., AHNER, B. A., FRIEDLAND, A. J.,MOREL, F. M. M. Role for heavy metals in forest decline indicated by phytochelatin measurements. Nature, 1996, vol. 381, no. 6577, pp. 64-65.

[14] MONTAGNESE, C., BARATTINI, P., GIUSTI, A., BALKA, G., BRUNO, U., BOSSIS, I., GELASAKIS, A., BONASSO, M., PHILMIS, P., DÉNES, L., PERANSI, S., RODRIGO, M., SIMÓN, S., GRIOL, A., WOZNIAKOWSKI, G., PODGORSKA, K., PUGLIESE, C., NANNUCCI, L., D'AURIA, S.,VARRIALE, A. A Diagnostic Device for In-Situ Detection of Swine Viral Diseases: The SWINOSTICS Project. Sensors, 2019 , vol. 19, no. 2, pp. 407-418.

[15] NASRIN, F., CHOWDHURY, A. D., TAKEMURA, K., LEE, J., ADEGOKE, O., DEO, V. K., ABE, F., SUZUKI, T.,PARK, E. Y. Single-step detection of norovirus tuning localized surface plasmon resonance-induced optical signal between gold nanoparticles and quantum dots. Biosens. Bioelectron., 2018, vol. 122, no. pp. 16-24. 